\title{
Brazilian position in the international fresh fruit trade network
}

\author{
Diego Rodrigues Bornal ${ }^{1}$, Murilo Mazzotti Silvestrini ${ }^{2}$, Leila Aparecida Salles Pio ${ }^{3}$, \\ Ana Claudia Costa ${ }^{4}$, Pedro Maranha Peche ${ }^{5}$, Martha Cristina Pereira Ramos ${ }^{6}$
}

\begin{abstract}
The fruit growing activity is of great importance for Brazilian agribusiness as the country is the third largest fruit producer in the world. Despite this notability, the fruit market presents obstacles especially related to international trade. Thus, the present study sought to determine the positioning and evolution of Brazil in the international fresh fruit market. Data used in the research were obtained from the Food and Agriculture Organization of the United Nations (FAO) (1986 to 2017) and the World Bank (2018), using metrics of export flow, quantity and income of countries related to the main fruits exported by Brazil in the first quarter of 2020. Data were manipulated, transformed into figures and graphs for better visualization of information. The Brazilian position in the in the ranking of fresh fruit exports was not very dynamic during the evaluation period, being dependent on the demand from high-income European countries.

Index terms: Foreign trade. Fruit growing. Graphs.
\end{abstract}

\section{Posicionamento do Brasil frente à rede internacional de comércio de frutas in natura}

Corresponding author:

diegobornal@hotmail.com

Received: March 17, 2021

Accepted: July 22, 2021

Copyright: All the contents of this journal, except where otherwise noted, is licensed under a Creative Commons Attribution License.
Resumo - A fruticultura tem grande importância no agronegócio brasileiro, pois o País é o terceiro maior produtor mundial de frutas. Apesar dessa notabilidade, o mercado de frutas apresenta entraves especialmente relacionados ao comércio internacional. Assim, o presente trabalho buscou determinar o posicionamento e a evolução do Brasil frente ao mercado internacional de frutas in natura. Os dados para a pesquisa foram obtidos a partir da Organização das Nações Unidas para Alimentação e Agricultura (FAO) (1986 a 2017) e Banco Mundial (2018), utilizando métricas de fluxo de exportação, quantidade e renda dos países em questão, relacionados às principais frutas exportadas pelo Brasil no primeiro trimestre de 2020. Os dados foram manipulados, transformados em figuras e grafos para melhor visualização das informações. O posicionamento do Brasil no ranking de exportação de frutas in natura mostrou-se pouco dinâmico durante o período avaliado, sendo dependente da demanda de países europeus de renda alta.

Termos para indexação: Comércio exterior. Fruticultura. Grafos.

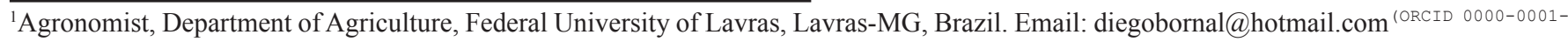
6869-3892)

${ }^{2}$ Master in Economics, Institute of Economics at State University of Campinas, Campinas-SP, Brazil. Email: muriloms@usp.br ${ }^{\text {(ORCID 0000- }}$ 0001- 9216-3971)

${ }^{3} \mathrm{PhD}$ in Agricultural Sciences, Department of Agriculture, Federal University of Lavras, Lavras-MG, Brazil. Email: leila.pio@ufla.br ${ }^{\text {(ORCID }}$ 0000-0001-5246-5035)

${ }^{4} \mathrm{PhD}$ in Agricultural Sciences, Department of Agriculture, Federal University of Lavras, Lavras-MG, Brazil. Email: anaclaudia.costa@ufla.br (ORCID 0000-0002-7939-4078)

${ }^{5} \mathrm{PhD}$ in Agricultural Sciences, Department of Agriculture, Federal University of Lavras, Lavras-MG, Brazil. Email: pedmpeche@gmail.com (ORCID 0000-0001-8865- 1702)

${ }^{6}$ Doctoral Student in Agronomy/Phytotechnics, Department of Agriculture, Federal University of Lavras, Lavras-MG, Brazil. Email: marthinha.ramos@yahoo.com.br(ORCID 0000-0003-1930-6723)
} 


\section{Introduction}

The fruit growing activity is of great importance for Brazilian agribusiness, as Brazil stands out as the third largest fruit producer in the world, only behind China and India (ABRAFRUTAS, 2019). Fruit production in Brazil in 2019 was 43 million tons in approximately 2.5 million cultivated hectares, generating revenue of around $\mathrm{R} \$$ 37 billion (IBGE, 2019). The harvest of 16.713 million tons of orange resulted in the highest revenue, totaling $\mathrm{R} \$ 9.450$ billion; the second largest revenue, $\mathrm{R} \$ 6.975$ billion, was obtained with the production of 6.752 million tons of bananas. Açaí had the third highest revenue, $\mathrm{R} \$ 3.265$ billion, with 1.510 million tons produced (ABRAFRUTAS, 2019).

In addition, the sector has great economic and social relevance, holding about $16 \%$ of all Brazilian agribusiness labor and generating approximately 5 million direct jobs (ABRAFRUTAS, 2018). The fruit growing activity is capable of generating an income multiplier effect, being an alternative for stagnant local economies with few alternatives to develop in the short term (SOUZA et al., 2018).

Although part of producers has reported high productivity levels in orchards, Brazil has incipient representativeness in the international fresh fruit market (OLIVEIRA; PEREIRA, 2019). Among several factors, the importance of logistics of the fruit market is highlighted, since this practice is fundamental to contemporary economic dynamics by contributing to preventing the strangulation of the country's circulation systems (SILVEIRA, 2015).

The fruit growing activity has great expansion capacity due to the growing demand of the population for healthy foods, sources of vitamins and minerals. Nevertheless, most of the Brazilian fruit production is destined to the domestic market (ABRAFRUTAS, 2019), placing the country in $15^{\text {th }}$ place in the ranking of the largest exporters. Of everything produced, $53 \%$ is destined to agro-industries, where $29 \%$ of this amount is sent to the foreign market, with the processing of concentrated frozen orange juice being the greatest contributor to this number, a product in which Brazil leads production and export. The remainder $47 \%$ is destined for fresh consumption, in which a small percentage of $2 \%$ is sent for export (VERAS, 2019). Brazil's participation in the foreign fruit market has increased every year, considering that Brazil has one of the largest fruit productions in the world. In addition, it has a growing production capacity, with areas capable of producing all year round, ensuring levels of supply when the foreign market is out of stocks. In the Brazilian case, these "windows" accelerated exports of temperate fruits, which could also favor the sales of tropical fruits (VITTI, 2009). According to Vitti and Boteon (2008), the statistical increase in exports in the fruit sector over the years is due to the combination of factors such as the adoption of new technologies in the productive sector and the access to new consumer markets.

Although there have been, over the last decades, different strategies and projects for the development of the fruit growing sector, production regions still need policies and strategies with emphasis on cooperation and innovation in order to improve the competitiveness of companies and local economic agents (LEÃO; MOLTINHO, 2014).

The use of technologies that help in the collection of statistical data on fruit exports and that expose the trajectory of Brazil to date can provide an organized view of the fruit market, which when used assertively, can be an essential tool to understand the Brazilian position compared to other world economies.

With these data, it will be possible to carry out a complex network analysis, which allows obtaining important information through the study of a structure, identifying the Brazilian position in relation to the international fruit trade network. According to Borba and Trevisan (2014), "a relevant aspect of analyzing a network is to decide which are the most important or central elements of it, using measures of centrality".

The present work aims to determine the position and evolution of Brazil in the international fresh fruit market.

\section{Material and methods}

This work is based on the analysis of data from the Food and Agriculture Organization (FAO) (FAOSTAT, 2019). FAO data include information on trade connections between specific countries for the period from 1986 to 2017. Variables from databases for analyzing the evolution of fruit trade between countries include: import/ export flow; type of imported/exported product; year of completion of transactions.

For this study, 26 products that represent the main fresh fruits exported by Brazil in the first quarter of 2020 were selected (ABRAFRUTAS, 2019). Table 1 presents the codes for identification in the FAO database and the description of selected products. 
Table 1. Codes and fresh fruits selected for analysis

\begin{tabular}{cc}
\hline Product code & Product \\
\hline 515 & Apples \\
526 & Apricots \\
572 & Avocados \\
486 & Bananas \\
531 & Cherries \\
249 & Coconuts \\
569 & Figs \\
619 & Fresh fruits * \\
603 & Fresh tropical fruits * \\
507 & Grapefruits \\
560 & Grapes \\
592 & Kiwis \\
497 & Lemons and Limes \\
571 & Mangos, mangosteens, guavas \\
568 & Melons, others \\
490 & Oranges \\
600 & Papayas \\
534 & Peaches and nectarines \\
521 & Pears \\
587 & Persimmons \\
574 & Pineapples \\
536 & Plums and sloes \\
523 & Quinces \\
544 & Strawberries \\
495 & Tangerines, mandarins and clementines \\
567 & Watermelons \\
\hline Source: FAO (2020). & \\
\hline
\end{tabular}

In addition to international trade data, for the categorization of countries according to income level, data from the World Bank (WORLD BANK) were used in the following classes: Low income (L); Lower middle income (LM); Upper middle income (UM); High income (H).

The FAO database for international food trade shows the correlation between country $i$ and country $j$ for a given product $x$. The interaction is characterized as an export, country $i$ exports a certain product $x$ to country $j$, or as an import, country $j$ imports a certain product $x$ from country $i$.

The mutual relationship between countries that make up the FAO database constitutes the adjacent matrix of international trade for each of the years from 1986 to 2017. Thus, the adjacent matrix A represents bilateral trade between country $i(1, \ldots, p)$ with country $j(1, \ldots, p)$ of product $x(1, \ldots, n)$, where the main diagonal is 0 (no country exports to or imports products from itself).

$$
A=\left[\begin{array}{ccccc}
0 & \cdots & a_{1 j}^{x} & \cdots & a_{1 p}^{n} \\
\vdots & & \vdots & & \vdots \\
a_{i 1}^{x} & \cdots & 0 & \cdots & a_{i p}^{x} \\
\vdots & & \vdots & & \vdots \\
a_{p 1}^{n} & \cdots & a_{p j}^{x} & \cdots & 0
\end{array}\right]
$$

Where $\mathrm{a}^{x}$ rij represents the marketed value of product $x$ between country $i$ and country $j$. In the FAO database for agriculture, the value $a$ is expressed in tons of selected fresh fruits.

Thus, $a_{i j}^{x}$ express the amount of product $x$ traded between country $i$ and country $j$. The sum of tons of the $n$ products selected between countries $i$ and $j$ results in the total value in tons of fresh fruits traded between the two countries:

$$
w_{i j}=\sum_{x}^{n} a_{i j}^{x}
$$

Where $w_{i j}$ expresses the value in tons of fresh fruits traded between country $i$ and country $j$. In the elaboration of networks of this study, nodes represent the countries and the connection between nodes, called vertices, correspond to $w$ values. In this way, networks that correspond to the international trade of fresh fruits (tons) in the period from 1986 to 2017 were structured.

In networks, the income classification of countries according to the World Bank (World Bank, 2018) was represented in the color of nodes. The diameter of nodes is related to the weighted entry degree of the node, that is, the level of tons that a given country receives (imports) from other countries. 
Two layouts for the construction of networks were used, OpenOrd (MARTIN et al., 2011), from which it is possible to identify the formation of clusters, and Frutcherman-Reingold (FRUCHTERMAN; REINGOLD, 1991), which is used to centralize nodes with greater importance within the network (both work with a fixed number of iterations, allowing analysis on directed graphs with large data volumes). Data manipulation, network modeling and data analysis were performed using the Python 3 language in the Gephi 0.9.2 software.

\section{Results and discussion}

The Brazilian position in the world ranking of fresh fruit exports can be considered stable during the period under study (1986-2017) (Figure 1), moving from $23^{\text {rd }}$ in 1986 to $27^{\text {th }}$ in 2017. The most significant changes occurred from 2002 to 2008 , alternating between the $18^{\text {th }}$ and $19^{\text {th }}$ position, when Brazil was in its best position, while from 2014 to 2017, it appeared in its worst position, increasingly approaching the $30^{\text {th }}$ position.

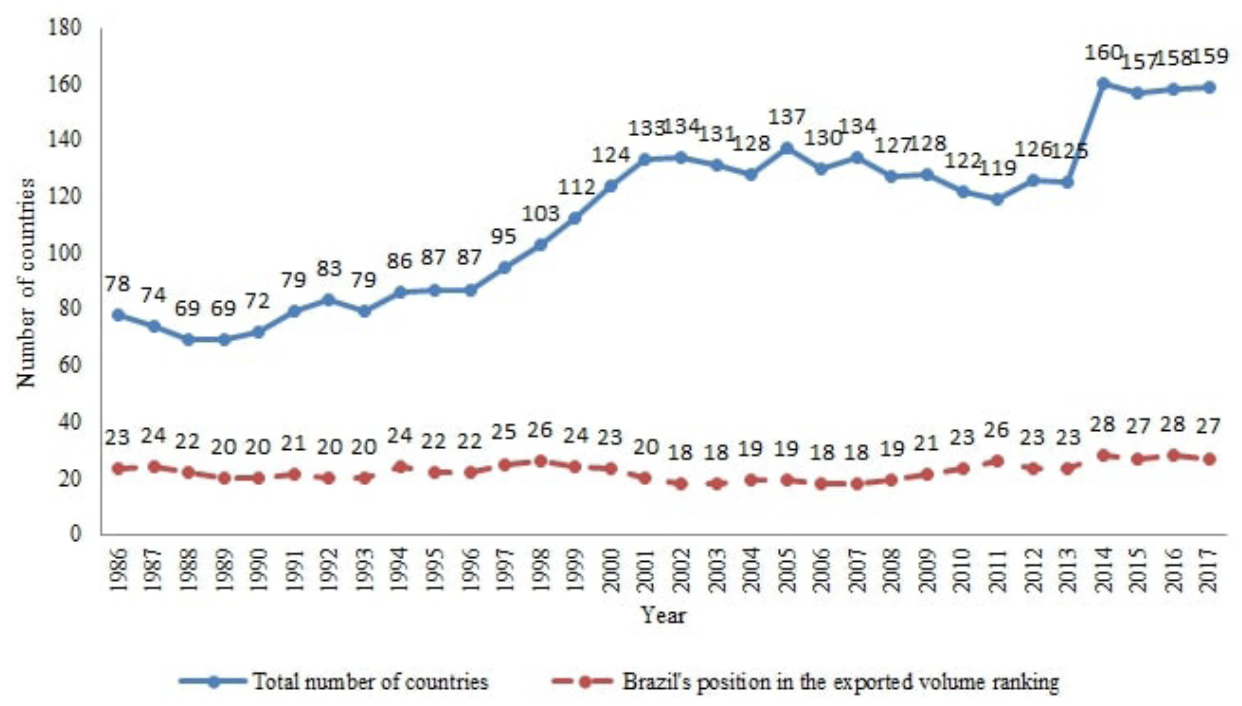

Figure 1 Number of fresh fruit exporting countries and Brazilian position in the ranking of exported volume per year. Source: Prepared by the author based on FAO data (2020).

According to Veras (2019), Brazil significantly increased its production volume from the 2000s onwards due to strong government investment in the Northeastern region, establishing irrigation conditions for producers, with the ultimate objective of exporting melon and seedless grapes. Despite this successful model, Brazil showed low evolution when compared to other countries.

From 2013 to 2014, the country dropped five positions in the ranking of fresh fruit exporting countries possibly because Brazil was no longer a beneficiary of the Generalized System of Preferences (GSP), an agreement of developed countries that aims to partially or fully reduce import taxes on certain agricultural products when they come from developing countries, which made Brazilian exports even more difficult, whose main customers are members of the European Union.

It is noteworthy that, in the sum of exported fresh fruit volume, Brazil does not appear at any time in a prominent position in the ranking. This lack of projection is mainly due to the lack of interest in entering the export market, with management aimed at the domestic market being implicit in the production culture in Brazil, which absorbs a large part of production and has lower health and quality requirements when compared to the European market, which discourages the attempt to adapt to parameters internationally required. From 1986 to 2017, the fresh fruit export market gained visibility, going from 78 exporting countries in 1986 to 159 in 2017 (Figure 1).

Among these 159 countries, Spain stands out (Figure 2), which remained at the top of the ranking of fresh fruit exports throughout the evaluated period (1986-2017), due to its participation in the European Union, which provides it privileges and preference in the international fruit market (VIANA et al., 2012). Spain is located in the Mediterranean Basin, which facilitates logistics and production flow, in addition to having packing-houses knowledge, making it one of the world's largest exporters of high-quality fresh fruits. 


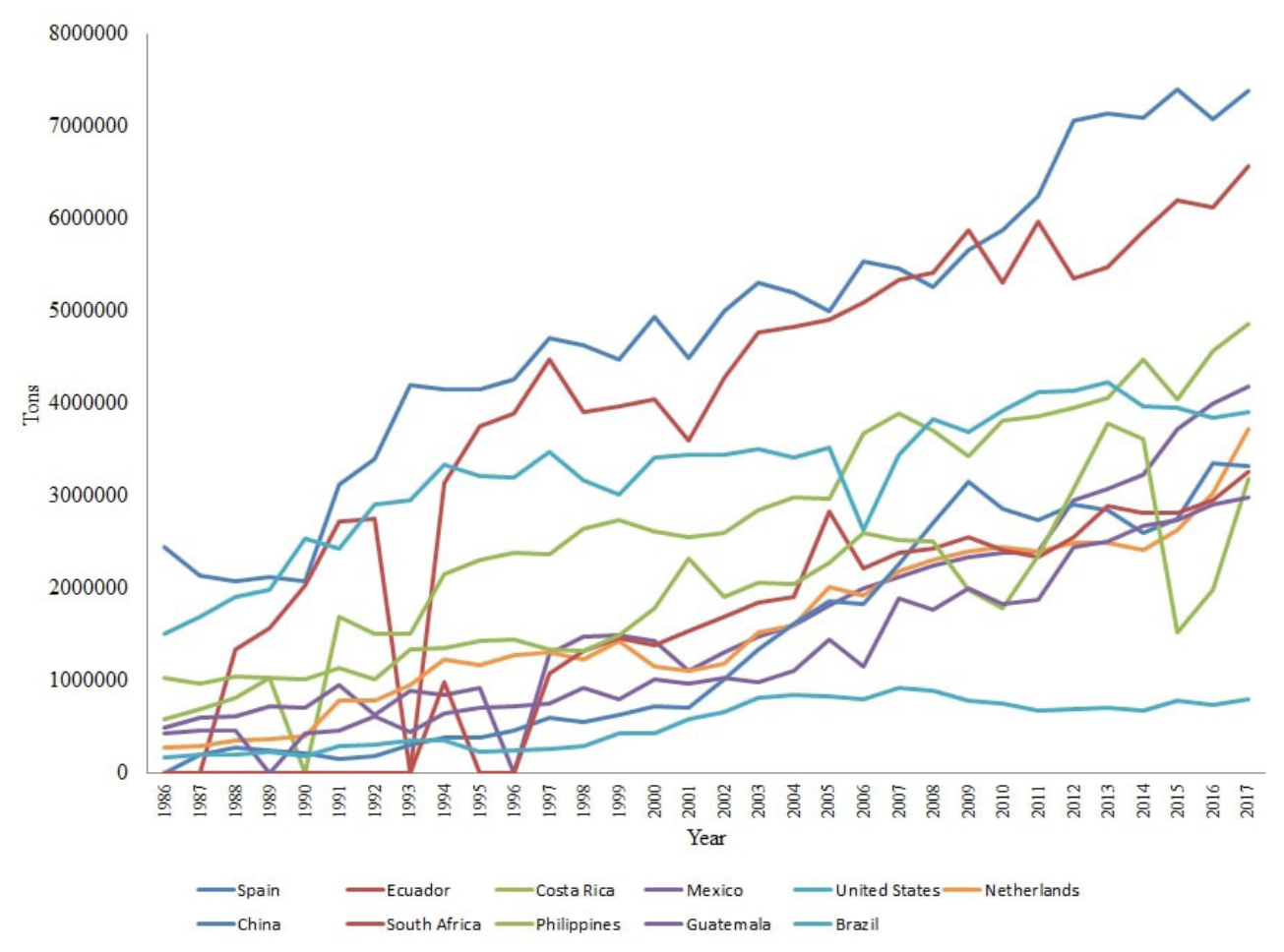

Figure 2. Evolution of exports of the 10 largest fresh fruit exporters in 2017 and Brazil. Source: Prepared by the author based on FAO data (2020).

The significant participation of Ecuador in the international fresh fruit market is due to strong government support, with investments from multinationals in the country's production, mostly using large irrigated rural properties located on the Ecuadorian coast for export.

Central American countries achieved good positions from the moment they decided to unite, creating organizations that favored the common market among member countries. The two most relevant projects are the Central American Common Market (CACM) and the Central American Bank for Economic Integration (CABEI), which directly finances projects linked to foreign trade and the development of member countries. Another important fact to be considered is that, in addition to the excellent climatic conditions for fruit production, these countries have cheap labor, which is attractive for multinationals to create production centers in these places.

A country that deserves special attention is the United States, as the two largest fruit exporting companies are American (Dole Food Company Inc. and Chiquita Brands International Inc.), which together hold $80 \%$ of the global banana market (ALBANO; SÁ, 2011). These large companies, when associated with government institutions that work seriously and effectively to help organize networks and reduce international barriers, result in great commercial opportunities.
The lack of government support in breaking tariff barriers, of international agreements that give preference to the Brazilian product, of infrastructure for production flow - many roads are precarious, or in many cases, do not have asphalt, reduce product quality - and the lack of planning, prevent Brazil from reaching its full export potential.

During the entire period under study, Brazil did not manage to reach one million tons of exported fresh fruits (Figure 2). Despite this, the number of countries importing fruits from Brazil has increased significantly (Figure 3).

From 1996 onwards, given the devaluation of the Brazilian currency and new trade agreements, it was possible to observe that, in addition to significantly increasing the number of countries with which Brazil does business, a new class of countries began to have greater importance within this context: developing countries. According to Oliveira and Pereira (2019), member countries of MERCOSUR, NAFTA economic blocks and countries in Latin America and the Caribbean stand out, which market was previously dominated by developed countries such as Germany, The Netherlands, Canada, United States, France, Italy, Japan and United Kingdom. This evolution was constant until 2008, followed by a fall in the following year due to the global financial crisis that started that year, but even so, emerging countries continued to have a significant share of imports of Brazilian products. 


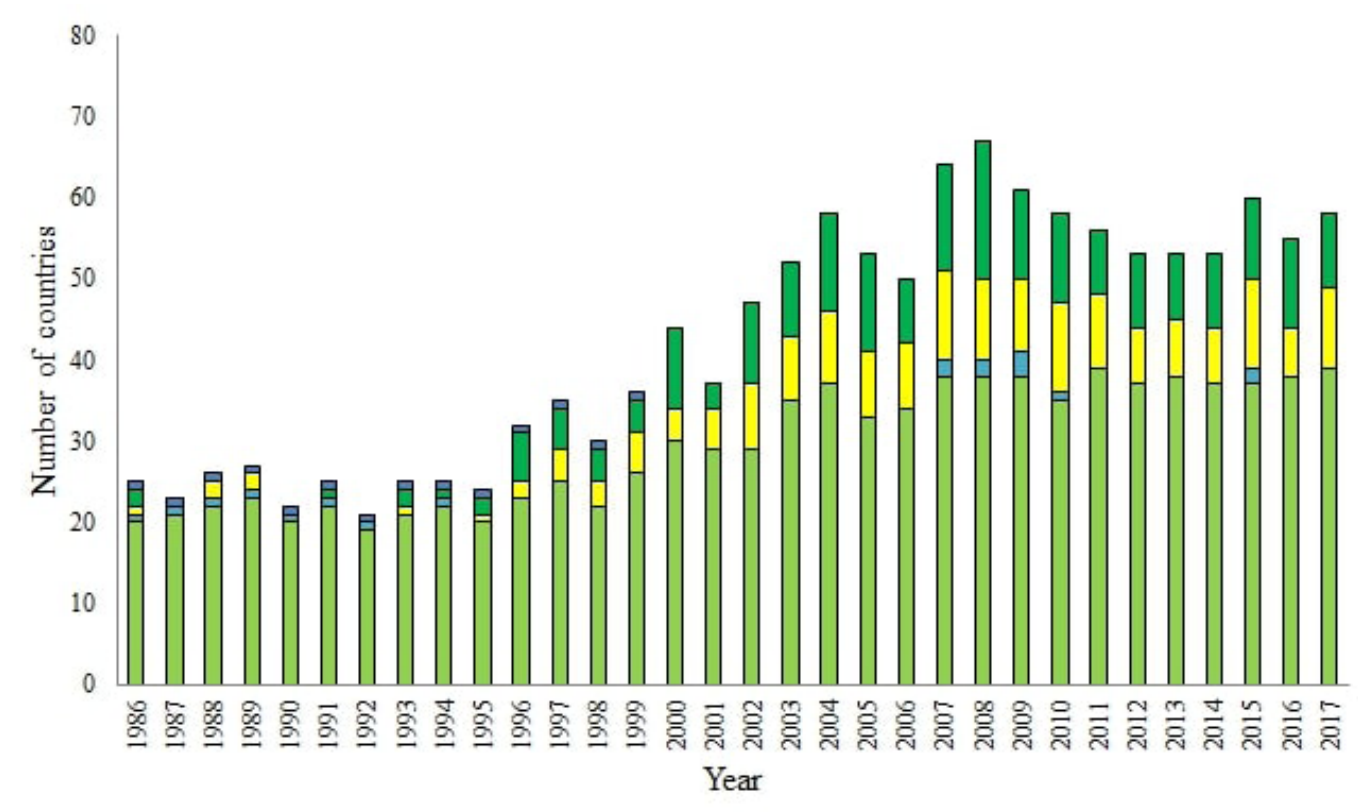

\section{$\square \mathrm{H} \quad \mathrm{L} \quad \mathrm{LLM} \square \mathrm{UM} \square \mathrm{ND}$}

Figure 3. Number of countries that import fresh fruits from Brazil grouped by income level class.Low income (L); Lower middle income (LM); Upper middle income (UM); High income (H); ND "not defined" - acronym used when the country class has not been defined by the World Bank. Source: Elaborated by the author based on FAO data (2020).

Export trade relations with these countries would result in significant reduction in storage and transport costs, as they are less demanding markets when compared to European countries, which gradually increases the number of attributes to be followed so that products from foreign markets are accepted (HORTIFRUTIBRASIL, 2017). According to Zanchi et al. (2013) "results point to the fact that the $1 \%$ increase in the distance between Brazil and each importing country reduces, on average, $4.5 \%$ of the Brazilian fresh fruit trade".

According to Teixeira (2008), the fruit growing activity has three types of products that can be internationally considered, universal products, those modified according to local requirements, and those fully customized for a given country. In general, the conditions imposed on imports by developing countries are lower, absorbing universal products, unlike developed countries, where imported products must have attributes of extrinsic order, where consumers do not mind paying extra for them, as long as they have certifications that guarantee their quality.

The number of countries importing fresh fruits from Brazil doubled from 1986 to 2007, and from 1997 onwards, middle-income countries began to appear in greater number (Figure 3).

Although fresh fruit imports have increased considerably in number of middle-income countries, the total amount imported by this market is still lower than the amount imported by high-income countries (Figure 4).
Europe is both a consolidated and a promising market, which has constantly increased the volume of fruits imported from Brazil. The drops observed were due to isolated facts: from 2009 onwards due to the global economic crisis; and, in 2016, when the northeastern region suffered a severe water crisis in fruit production regions, which directly affected productivity, quality and reduced exports.

In addition, the European population is older than the rest of the world, and people are more concerned about their own health, consuming more fruits and vegetables. According to Pinheiro and Pinheiro (2009), products with value attributes will be preferred over conventional products.

Of the 800,000 tons of fruits exported by Brazil in 2017 , more than 750,000 went to high-income countries, which is greater than the sum of thirty years for middleincome countries (Figure 4).

The next figures show the analyses of Brazil's complex network within the world scenario for the years 1986, 1996, 2006 and 2017, with a figure for each year aiming at a better visualization of the Brazilian position within the world network. The analyzed data period extends for 30 years; thus, the four years were selected seeking to observe the extremes of the period (first and last year of available data) and two years between these extremes, which allows analyzing the evolution in the period. As the first year of available data was 1986, it was sought to explore the evolution every 10 years, defining the last as 2017 as it is the last year available. 


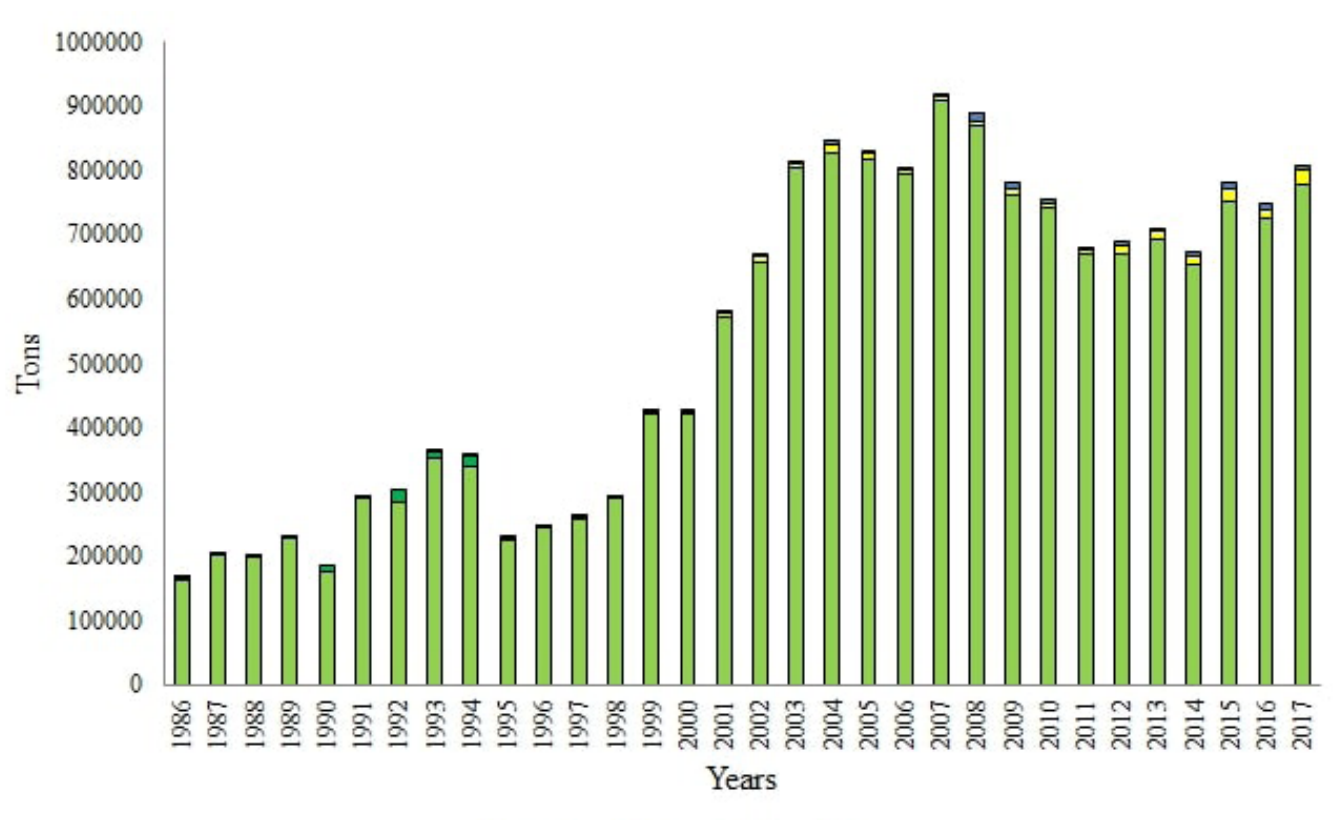

$\square \mathrm{H} \square \mathrm{L} \quad \mathrm{LM} \square \mathrm{UM} \square \mathrm{ND}$

Figure 4. Volume (tons) of fresh fruit exported by Brazil and export destination grouped by income level class. Low income (L); Lower middle income (LM); Upper middle income (UM); High income (H); ND "not defined" - acronym used when the country class has not been defined by the World Bank.

Source: Elaborated by the author based on FAO data (2020).

Two distinct algorithms were used for modeling networks, seeking to expand the analysis and understanding within the fresh fruit trade. The algorithm used for figures indicated with letter (a) is the Open Ord, which offers a view towards the formation of clusters, while the algorithm indicated with letter (b) is the Fruchterman Reingold, which provides greater understanding of the centrality of nodes, in which, the more towards the center of the figure, the greater its importance within the network.

The tables presented below will be used as a subsidy to support the results. Table 2 refers to the network in general, while Table 3 represents only the Brazilian node.

Table 2. Network analysis metrics of 1986, 1996, 2006 and 2017.

\begin{tabular}{ccccc}
\hline Metrics & $\mathbf{1 9 8 6}$ & $\mathbf{1 9 9 6}$ & $\mathbf{2 0 0 6}$ & $\mathbf{2 0 1 7}$ \\
\hline Number of nodes & 152 & 188 & 194 & 201 \\
Number of edges & 1357 & 2152 & 3222 & 4197 \\
Average degree & 8.928 & 11.447 & 16.608 & 21.090 \\
Average weighted degree & 105243.9 & 183817.6 & 278361.1 & 406599.1 \\
Density & 0.059 & 0.061 & 0.086 & 0.107 \\
Modularity & 0.258 & 0.149 & 0.148 & 0.305 \\
\hline
\end{tabular}

Source: Elaborated by the author based on FAO data (2020).

Table 3. Node analysis metrics for Brazil in 1986, 1996, 2006 and 2017.

\begin{tabular}{ccccc}
\hline Metrics & $\mathbf{1 9 8 6}$ & $\mathbf{1 9 9 6}$ & $\mathbf{2 0 0 6}$ & $\mathbf{2 0 1 7}$ \\
\hline Income class & $\mathrm{UM}$ & $\mathrm{UM}$ & $\mathrm{UM}$ & $\mathrm{UM}$ \\
Entry degree & 10 & 18 & 18 & 20 \\
Exit degree & 25 & 30 & 48 & 57 \\
Degree & 35 & 48 & 66 & 77 \\
Weighted entry degree & 118709 & 393585 & 271251 & 363864 \\
Weighted exit degree & 164958 & 247488 & 802578 & 807676 \\
Weighted degree & 283667 & 641073 & 1073829 & 1171540 \\
Closeness Centrality & 0.516 & 0.501 & 0.542 & 0.581 \\
Harmonic Closeness Centrality & 0.566 & 0.557 & 0.609 & 0.642 \\
\hline
\end{tabular}

Source: Elaborated by the author based on FAO data (2020). 
In the structure of networks, the diameter of each node is related to the volume that the country represented by the node imported in a given year, weighted by the imports of the entire network. Thus, larger nodes indicate greater imported volume, while smaller nodes indicate lower imported volume. This structure allows identifying countries with the highest volume of imported fruits and their position in the international trade network (centrality in the network and approximation to the other nodes).

Another relevant network structure for analyses is the relative positioning of each node, that is, the approximation of countries in the network. As the modeling of networks used exports as weight, the edges and the network modeling algorithms position nodes (countries) according to their relationship with the other nodes. Thus, the formation of clusters and their composition (nearby countries and countries with central position in networks and clusters) can be identified.

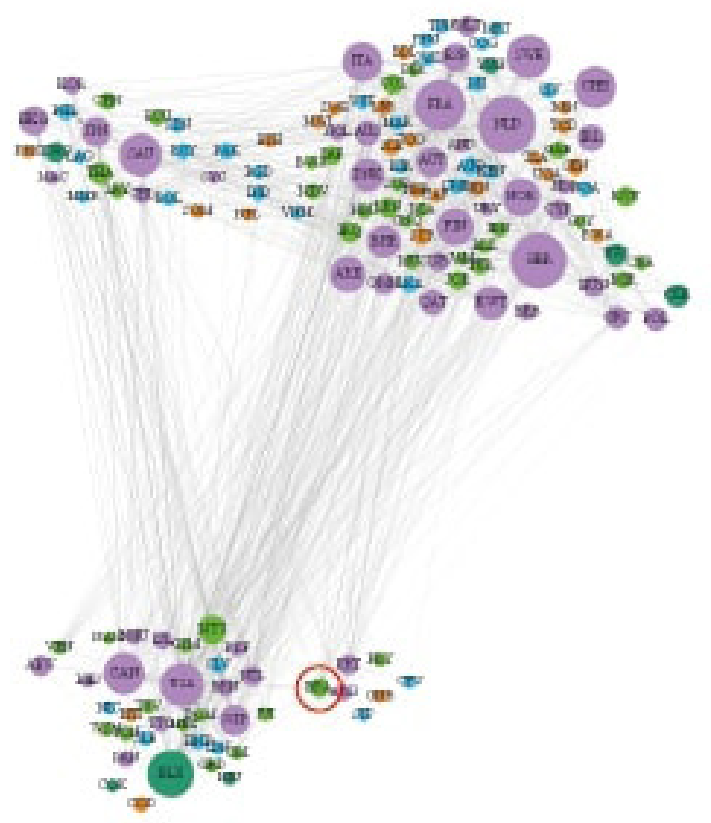

(a)

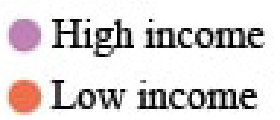 \\ Low income}

The year 1986 is marked as the year with the lowest number of nodes, edges and average degrees, which indicates how many nodes on average each country was related to (Table 2).

Clusters are clearly separated by local trade characteristics, with one European, one American and an Eastern one, of which the Netherlands (NLD), Great Britain (GRB), United States (USA), Canada (CAN) and Saudi Arabia (SAU) stand out within their respective clusters (a).

When the network centrality is analyzed (b), it is clear that Brazil (BRA) is close to the center, not due to its low import quantity, but because large part of its export is destined to European countries, which are the most influential within the complex fresh fruit trade network, while low-income countries appear with little importance, most of them appearing only at the edge of it (b).

Figure 5 indicates that in 1986, conditions were unfavorable to the international fresh fruit trade for long distances, probably due to the lack of storage and transport technologies for this purpose. Such technologies emerged and were improved in the following decades. Furthermore, the different geopolitical moments also impact on foreign trade.

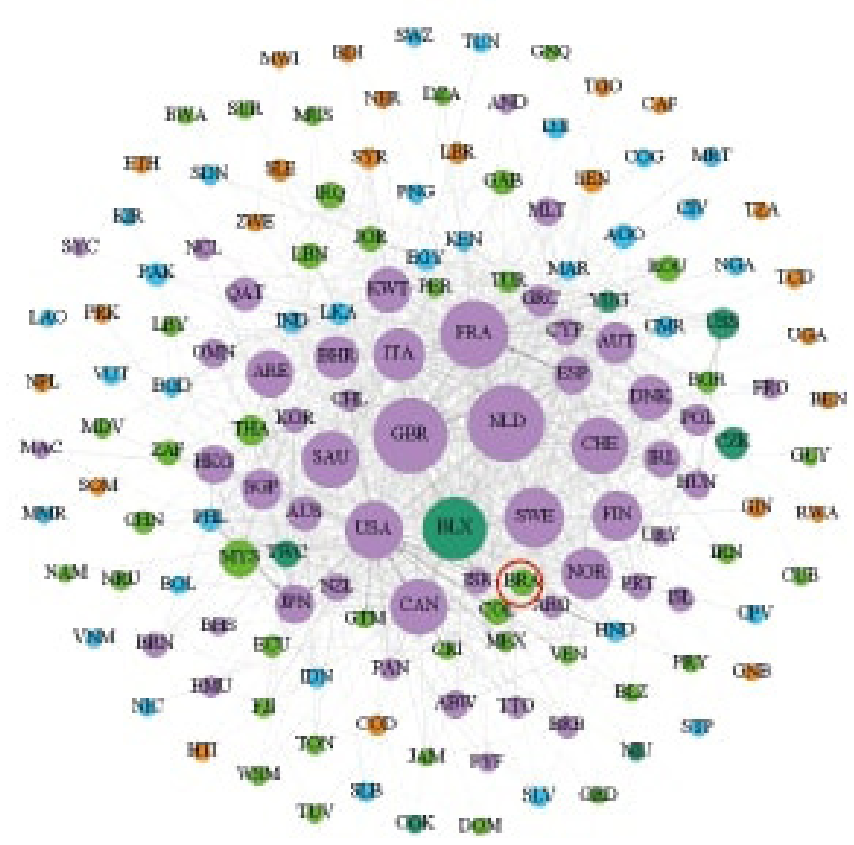

(b)
Upper middle income Not defined*
Lower middle income Brazil

Figure 5. Fresh fruit international trade network (tons) in 1986.(a) Layout with Open Ord algorithm,(b) Layout with Fruchterman Reingold algorithm,* Countries without class identification in the World Bank data.Source: Elaborated by the author based on FAO data (2020). 
The year 1996 presented significant increase in the number of participating countries, and consequently, in the number of connections between nodes (Table 2). Clusters are more heterogeneous, with significant increase in the number of countries within them, evidencing the strengthening of the globalization trend. Despite this, the network structure remains with little change, in which high-income countries exert greater influence (b).

In 1986 and 1996, Brazil presented weighted entry degree higher than the weighted exit degree, showing that in these periods, the country's relationship in the international fresh fruit trade network was of more dependence on other countries than as product supplier. In 2006, there was a change in this relationship, with Brazil presenting higher value for the weighted exit degree in relation to the weighted entry degree, this position remaining in 2017. Thus, from 2006 onwards, the country positioned itself in the network with characteristic of product supplier than of consumer, starting to export more than to import (Table 3).
According to (AMARO; VIEIRA; MAIA et al., 1998), this behavior is mainly due to the adoption of the new foreign insertion policy in the Brazilian market, mainly by MERCOSUR member countries. These policies stimulated the development of production structures, seeking previously unexplored foreign markets, which over the following years strengthened the Brazilian position as an important supplier in the international market. Thus, the country presented a position of greater centrality than other countries that appear as the ten largest exporters at the end of the $20^{\text {th }}$ century and beginning of the $21^{\text {st }}$ century, such as Costa Rica (CRI) and Guatemala (GTM) (Figure $6 \mathrm{~b}$ and Figure 3).

Within the international fresh fruit trade, the decade of 2000 presented significant change regarding the connective capacity, especially with regard to transport and storage technology (especially the use of low temperatures and controlled atmosphere methods), which were decisive for the connections between nodes to increase (Figure 6). The improvement of these techniques allowed the use of less intense post-harvest treatment, cost reduction and quality improvement through the possibility of harvesting riper fruits (FAVERET FILHO; ORMOND; PAULA, 1999).

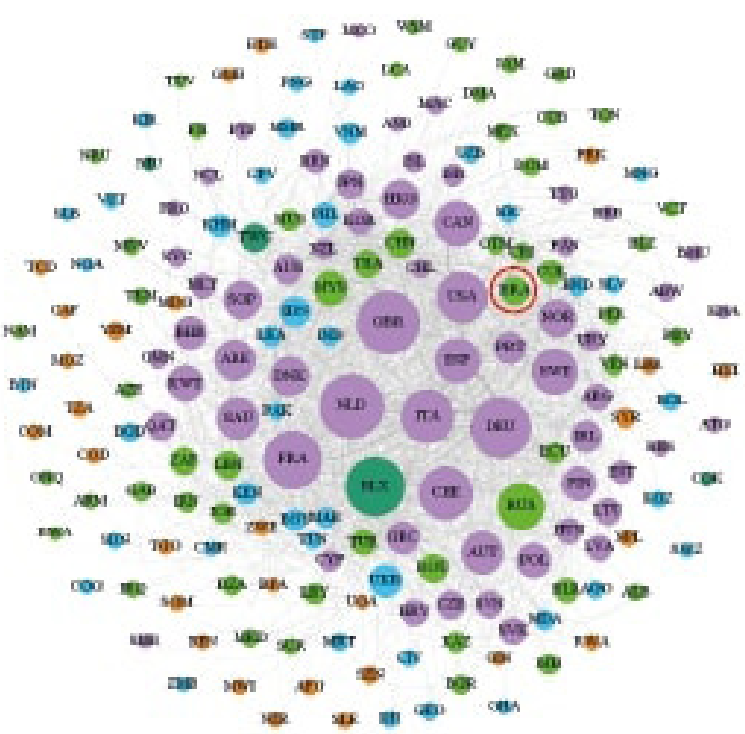

(b) (a)

\section{High income \\ Low income}

Upper middle income Not defined*

\section{Lower middle income} Brazil

Figure 6. Fresh fruit international trade network (tons) in 1996.(a) Layout with Open Ord algorithm, (b) Layout with Fruchterman Reingold algorithm, * Countries without class identification in the World Bank data. Source: Elaborated by the author based on FAO data (2020). 
Technological advances together with greater accessibility and use allowed countries to develop their production chains and increase the supply of products on the international market. On the other hand, economic advances from the $21^{\text {st }}$ century and changes in consumption habits impacted the volume of food demanded (VIANA et al., 2012). These changes related to the volume of products offered and demanded over the years influenced the composition and behavior of countries in the international fresh fruit market. In the network modeled for the year 2006 (Figure 7), the formation of a cluster that covers most nodes is observed, allowing the identification of a greater relationship between countries related to the weight of each connection (edge) composed of the volume traded between two countries.

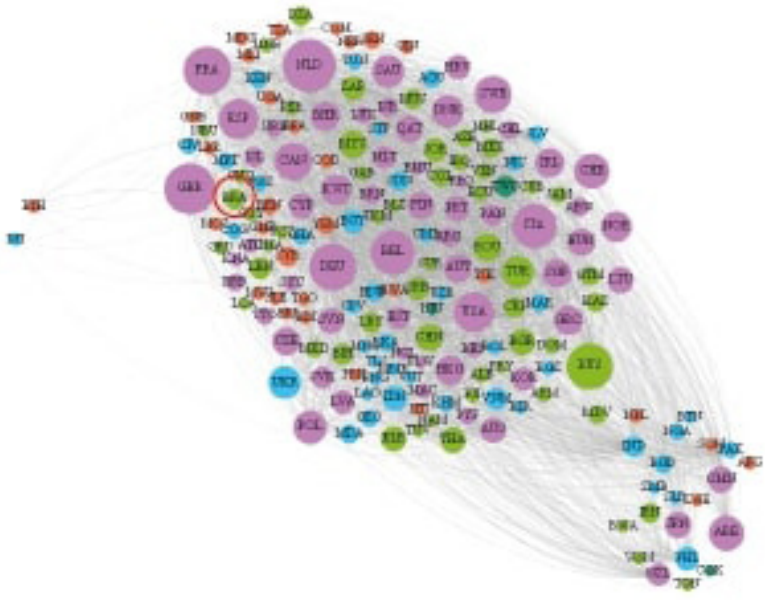

(a)

Upper middle income
Not defined*
Not defined*

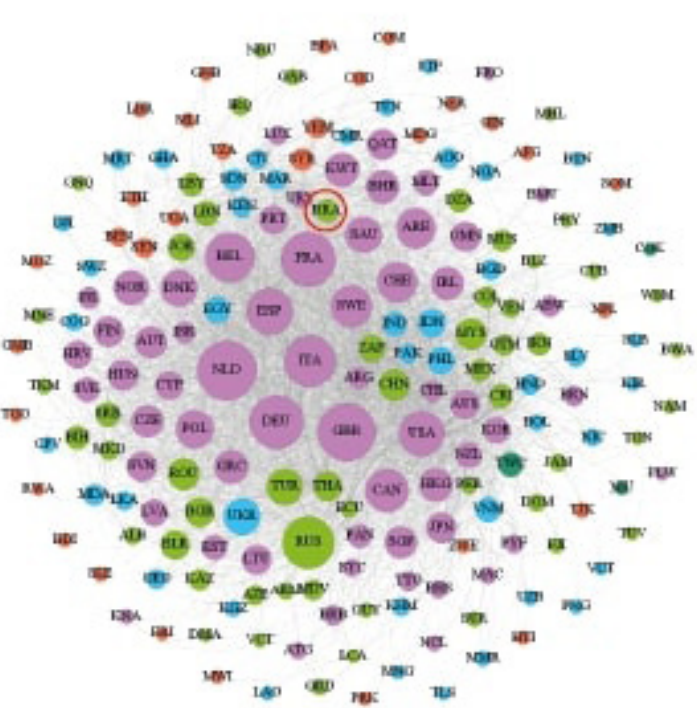

(b)
High income Low income
Lower middle income Brazil

Figure 7. Fresh fruit international trade network (tons) in 2006. (a) Layout with Open Ord algorithm, (b) Layout with Fruchterman Reingold algorithm, ${ }^{*}$ Countries without class identification in the World Bank data. Source: Elaborated by the author based on FAO data (2020).

The neighbors of the Brazilian node change significantly, and countries like Bahrain (BHR), United Arab Emirates (ARE) and Kuwait (KWT) emerged, allowing identifying an increase in the fresh fruit trade relations between Brazil and eastern countries and, in a certain way, the diversification of Brazilian export destinations. The center is no longer dominated by highincome countries, and South Africa (ZAF), India (IND), Indonesia (IDN), China (CHN), Pakistan (PAK) and the Philippines (PHL) appear near the center; however, with node diameter still small compared to European countries (b).

In 2006, Brazil presented a relevant evolution in the trade balance, reducing fruit imports by approximately 100,000 tons and increasing exports by 550,000 tons, a decrease of $31.08 \%$ and an increase of $224.28 \%$, respectively, compared to 1996 (Table 3). According to Santos (2006), this rise is due to government policy during the years preceding the analysis, which had as pillars the defense of agriculture and the promotion of exports with greater added value, supporting this idea through the creation of programs to leverage the fruit growing activity, such as the Integrated Fruit Production (PIF), Support for the Development of Irrigated Fruit Growing in Northeastern Brazil and the Fruit Growing Development Program (PRODEFRUTA). Furthermore, technologies were incorporated by sectors of the fruitgrowing agribusiness (such as the hydrothermal treatment of mangoes, which leveraged exports of mangos from Petrolina - PE).

Although Brazil has considerably increased its numbers within international trade, the diameter of its node has not increased (Figure 7), as the other nodes have also evolved at the same rate. Thus, what placed Brazil in a privileged position close to the center (Figure 7) is its number of connections, of which the average among countries is 16 (Table 2), while the Brazilian node is 66 (Table 3). 
The year 2017 has greater number of nodes, edges, average degrees, weighted average degrees, density and modularity (Table 2), showing a more structured network, with greater number of connections than in previous years analyzed and better distribution of importance within the network, indicating that the international fresh fruit trade has evolved steadily over the years, in which upper-middle-income countries and lower-middle-income countries began to appear more prominently (Figure 8). Despite this greater share, the international fresh fruit trade remains dependent on high-income importers.

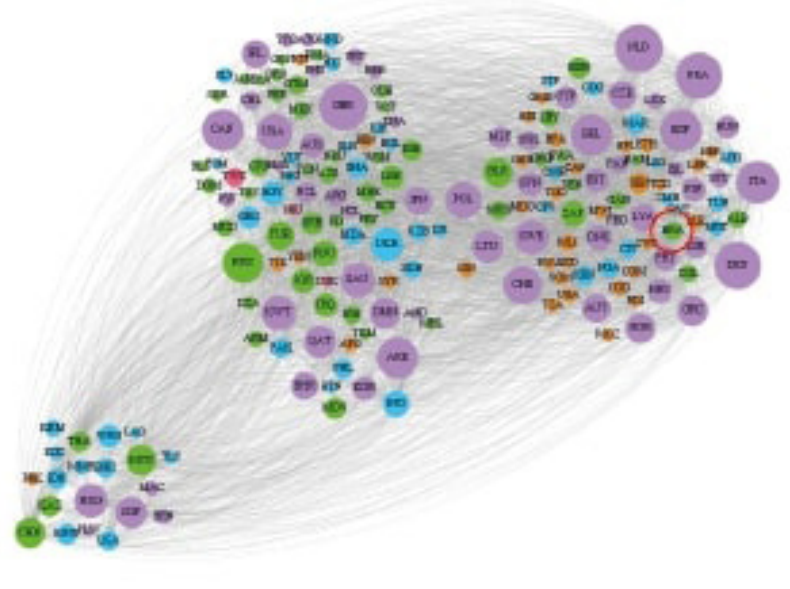

(a)

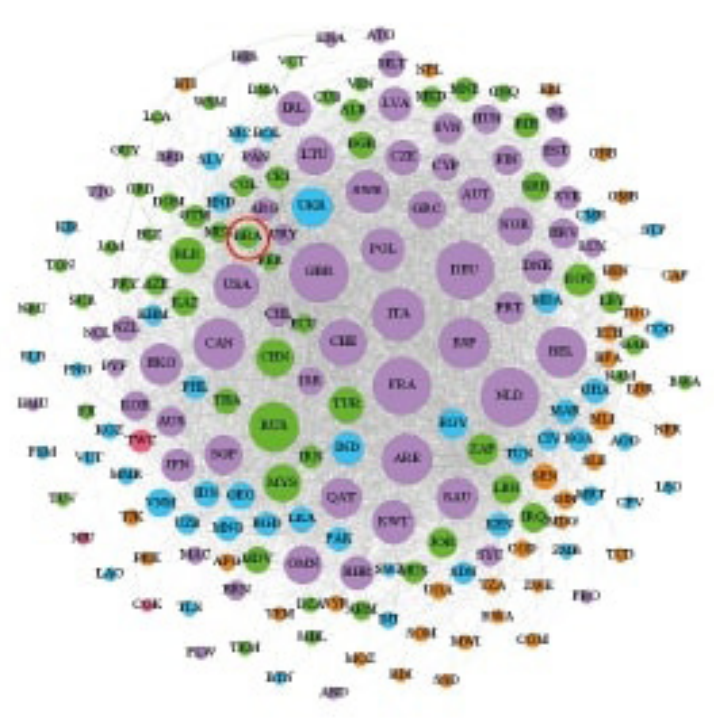

(b)

\section{High income \\ Low income}

Upper middle income
Not defined*

\section{Lower middle income OBrazil}

Figure 8. International fresh fruit trade network (tons) in 2017. (a) Layout with Open Ord algorithm, (b) Layout with Fruchterman Reingold algorithm.* Countries without class identification in the World Bank data.Source: Elaborated by the author based on FAO data (2020).

The centrality of the Brazilian node is close to countries with characteristics similar to its own in the international fruit market (Figure 8), such as Argentina (ARG), Uruguay (URY), Mexico (MEX), Guatemala (GTM), Costa Rica (CRI), Honduras (HON) and Colombia (COL). Due to the geographic proximity and logistical trade characteristics, there was a commercial approach between Brazil and these countries, causing an increase in the flow of fresh fruits between markets of Central America, Latin America and Mexico.

The modeling of the complex international fresh fruit trade networks together with the exploration of data and analysis of metrics coming from the networks proved to be an alternative tool that presents important information and trade characteristics in the world. It allows exploring the relationships between countries and the evolution over the years, enabling a spatial analysis and providing important information for the positioning of market players and development of policies related to international trade.
There are few works using this approach for specific groups of agricultural products in the trade context. Thus, further studies should explore this type of method, the development of the methodology and the deepening of issues that involve the international fresh fruit trade and the Brazilian position.

\section{Conclusion}

The Brazilian position in the ranking of fresh fruit exports was not very dynamic during the evaluation period. However, using complex network modeling, it was possible to identify the country's evolution in the international market network.

The country was positioned in clusters composed of European and high-income countries, with characteristics of consuming a high volume of fresh products from lower-income countries with dependence on the trade of agricultural products. In the last years of analysis, an approximation of Brazil to nodes of Latin American countries was observed. 
Regarding quantitative issues, there was a change in the leadership from weighted entry degree to weighted exit degree, showing the evolution of Brazil in being a great supplier of products instead of a great consumer.

\section{References}

ABRAFRUTAS - Associação Brasileira dos Produtores Exportadores de Frutas e Derivados. O Brasil é o terceiro maior produtor de frutas no mundo. 2019. Disponível em: https://abrafrutas.org/2019/03/07/brasil-e-o-terceiromaior-produtor-de-frutas-do-mundo-diz-abrafrutas/. Acesso em: 25 jul. 2020.

ABRAFRUTAS - Associação Brasileira dos Produtores Exportadores de Frutas e Derivados. Fruticultura - Setor em Expansão. 2018. Disponível em: $<$ https://abrafrutas. org/2018/08/fruticultura-setor-em-expansao/>. Acesso em: 06 mai. 2021.

ALBANO, G.P.; SÁ, A.J. Impacto das multinacionais de bananas no Nordeste do Brasil. Revista Geográfica de América Central, Costa Rica, v.2, n.esp, p.1-17, 2011.

AMARO, A.A.; VIEIRA, L.C.; MAIA, M.L. Fruticultura brasileira e o Mercosul. Informações Econômicas, São Paulo, v.28, n.3, p.7-20, 1998.

BORBA, E. M.; TREVISAN, V. Medidas de Centralidade em Grafos e Aplicações em redes de dados. Proceeding Series of the Brazilian Society of Applied and Computational Mathematics, São Carlos, v.2, n.1, p.16, 2014.

FAO. Food and Agriculture Organization of the United Nations. FAOSTAT. 2019. Disponível em: http://www. fao.org/faostat/en/\#home. Acesso em: 28 jan.2021.

FAVERET FILHO, P.S.C.; ORMOND, J.G.P.; PAULA, S.R.L. Fruticultura brasileira: a busca de um modelo exportador. Rio de Janeiro: Banco Nacional de Desenvolvimento Econômico e Social, 1999. 226p.

FRUCHTERMAN, T.M.J.; REINGOLD, E.M. Graph drawing by force $\square$ directed placement. Software: Practice and Experience, London, v.21, n.11, p.11291164, 1991.

HORTIFRUTIBRASIL. Valorizar a fruta brasileira: eis o grande desafio! 2017. Disponível em: https://www. hfbrasil.org.br/br/revista/acessar/completo/ha-espacopara-exportar-mais-a-uniao-europeia.aspx. Acesso em: 23 mai. 2021.
IBGE. Levantamento Sistemático da Produção Agrícola - LSPA. Rio de Janeiro, 2019. Disponível em: https://www.ibge.gov.br/estatisticas/economicas/ agricultura-e-pecuaria/9201levantamento-sistematicoda-producao-agricola.html $?=\& \mathrm{t}=\mathrm{o}-$ que-e. Acesso em: 28 jul. 2020.

LEÃO, E.L.S.; MOUTINHO, L.M.G. O arranjo produtivo local de fruticultura irrigada do Vale do Submédio do São Francisco como objeto de política. Race, Joaçaba, v.13, n.3, p.829-858, 2014.

MARTIN, S; BROWN, W.M.; KLAVANS, R.; BOYACK, K.W. OpenOrd: An Open-Source toolbox for large graph layout. In: THE INTERNATIONAL SOCIETY FOR OPTICAL ENGINEERING, 2011, San Diego. Proceedings [...]. San Diego: SPIE, 2011.

OLIVEIRA, I.M.; PEREIRA, L.A.G. Redes de comércio internacional e logística de exportação de frutas no Brasil. Geografia em Questão, Marechal Cândido Rondon v.12, n.2, p.75 - 95, 2019.

PINHEIRO, F.A.; PINHEIRO, A.V.B.S. Processos de certificação para exportação de frutas frescas brasileiras. In: ENCONTRO NACIONAL DE ENGENHARIA DE PRODUÇÃO, 29., 2009. Salvador. Anais [...]. p.14.

SANTOS, F.L. Desempenho recente da fruticultura brasileira no cenário internacional: a participação da política comercial e dos programas de apoio na retomada do market share. Informações Econômicas, São Paulo, v.35, n.5, 2006.

SILVEIRA, M.R. Circulação, transportes, logística e a dinâmica capitalista: alguns apontamentos sobre as recentes reestruturações no Brasil. In: ARROYO, M.; CRUZ, R.C.A. Território e circulação: a dinâmica contraditória da globalização. São Paulo: FAPESP/PPGH/ CAPES/Annablume Geografias, 2015. p.51-73.

SOUZA, H.G.; TABOSA, F.J.S.; CAMPOS, K.C.; VIEIRA FILHO, J.E.R.; NEDER, H.D. Análise da projeção espacial da fruticultura no nordeste brasileiro. Revista Econômica do Nordeste, Fortaleza, v.49, n.4, p.121-141, 2018.

TEIXEIRA, L. Posicionamento de frutas brasileiras no exterior do ponto de vista do consumidor: um estudo comparativo da imagem de frutas estrangeiras no mercado holandês. 2008. Dissertação (Mestrado em Administração de Organizações) - Faculdade de Economia, Administração e Contabilidade de Ribeirão Preto, Universidade de São Paulo. Ribeirão Preto, 2008. 
VERAS, T.T.G. A evolução do desempenho das exportações agrícolas brasileiras destacando a contribuição da fruticultura e a produção do melão do Rio Grande do Norte no período de 1997 a 2017. 2019. Monografia (Graduação em Economia) - Departamento de Ciências Econômicas, Centro de Ciências Sociais Aplicadas, Universidade Federal do Rio Grande do Norte, Natal, 2019.

VIANA, M.M.; JULIÃO, L.; SOARES, A.F.; SANTOS, G.R. Mercado de frutas na União Europeia: Há mais espaço para os produtos brasileiros? Hortifruti Brasil, Piracicaba, n.117, p.8-26, 2012.
VITTI, A.; BOTEON, M. Análise da competitividade da fruticultura brasileira frente a mundial. In: CONGRESSO DA SOCIEDADE BRASILEIRA DE ECONOMIA E SOCIEDADE RURAL, 46., 2008, Rio Branco. Anais [...]. Rio Branco: USP, 2008. 13 p.

VITTI, A. Análise da competitividade das exportações brasileiras de frutas selecionadas no mercado internacional. 2009. Tese (Doutorado em Ciências) - Economia Aplicada, Universidade de São Paulo, Piracicaba, 2009.

ZANCHI, V.V.; COSTA, E.F.; SCHWANTES, F.; XAVIER, L.F. Desempenho das exportações brasileiras de frutas in natura (1996-2007): uma análise sob a ótica do modelo gravitacional. Revista Teoria e Evidência Econômica, Passo Fundo, v.19, n.41, p.9-34, 2013. 